\title{
Exploring the Impact and Management Strategies for Hailstorm Associated Loss and Damage among Smallholder Farmers in Poverty Prone Northern Bangladesh
}

\author{
Mohammad Mahbubur Rahman ${ }^{1 *}$, Mizanur Rahman Bijoy ${ }^{2}$ \\ ${ }^{1}$ Center for People \& Environ (CPE), Dhaka, Bangladesh \\ ${ }^{2}$ Network on Climate Change in Bangladesh (NCC,B) \\ Dhaka, Bangladesh \\ *Corresponding Author: mmrahman.ju39@gmail.com
}

\begin{abstract}
Climate change causes weather extremes to rise in frequency and severity, which could have detrimental effects on human life, property and livelihood activity. There is significant uncertainty about the influences of anthropogenic climate change on the occurrence and severity of small-scale, sudden onset weather phenomena such as hailstorms and subsequent loss and damage. Yet, several studies indicate that there is an apparent stable connection between hailstorm activity and hailstorm damage. Severe hailstorm events are observed in Bangladesh in recent years, which are, in fact, rapid-onset disasters but low exposure in terms of giving government response and media consideration. Hence this study examines potential impacts and management strategies for loss and damage resulting from hailstorm events among smallholder farmers in Kurigram District's Phulbari Upazila of Bangladesh. Firstly, the direct and long term economic and non-economic loss and damage caused by the hailstorm on human well-beings and livelihoods were assessed. Then, the study evaluated the current adaptation, coping, management and response strategies at the institutional and community level in the context of such extreme events. Finally, a regulatory framework and implementation approaches had suggested achieving the country's resilience against disaster and climate change-induced loss and damage. Participatory Vulnerability Analysis, Key Informant Interviews and Sample Surveys accumulated the primary data for the study. In addition, secondary data were collected through analysis of literature, published and unpublished scientific articles and media reports, etc. This research outcome will help countries develop a guideline to address climate change and disasterrelated loss and damage.
\end{abstract}

Keywords: Climate Change, Loss and Damage, Hailstorm, Impact on Agriculture and Livelihood, Adaptation Options, Response, policy suggestions, Bangladesh 


\section{Introduction}

The global climate is shifting, and it will proceed to change throughout the twenty-first century and beyond. Rising temperatures, changing precipitation patterns and other weather variability's have already affected many aspects of human civilization and the natural environment. Climate change is a global-scale phenomenon, but at the same time, it has diverse regional indications (National Research Council, 2008). Thus, the changing pattern of global climate may cause an increase in the frequency and intensity of weather extremes, both sudden and slow-onset disasters, which could have adverse consequences on human life, properties and economic activities throughout the world (IPCC, 2007).

\subsection{Understanding of Climate Change and Its Future prediction}

Climate change refers to trends and fluctuations in climatic factors, such as $\mathrm{CO}_{2}$ content of the atmosphere, temperature and rainfall (Warwick et al., 1993; IPCC, 1990; Eliot et al., 1999). These changes occur at time scales up to 100 years and maybe irreversible. Changes predicted to emerge from the 'greenhouse effect' provide examples of the type of variability to be considered in vulnerability assessment. However, other fluctuations in climate may be equally important at this scale. Natural climate variability makes it unlikely that the order in changes suggested by various global climate models may have confirmed for decades (McQuade et al., 1996; Eliot et al., 1999). Hence the natural variability of local climatic conditions should be examined as part of the vulnerability assessment process. The natural trends, oscillations and more random perturbations in climate need to be identified and distinguished from more 'exotic' changes caused by human populations (Eliot et al., 1999). There are specific scientific predictions that climate change may increase the frequency and intensity of weather extremes, both sudden and slow-onset disasters, which could have adverse consequences on human life, properties and economic activities (IPCC, 2007; 2014). Earlier, Cruz et al. (2007) and Field et al. (2012) warned that climate change might increase the frequency and intensity of weather extremes, both sudden and slow-onset disasters, including heat waves, tropical cyclones, prolonged dry spells, intense rainfall, tornadoes, thunderstorms, and severe dust storms in many parts of Asia. These extreme climatic events could have adverse consequences ranging from hunger to disease to loss of income and livelihoods, affecting human survival and well-being.

\subsection{Climate Change and Predicted Impacts on Bangladesh}

Bangladesh is among the most vulnerable in the world to the effects of climate change. Bangladesh was the seventh most climate-vulnerable country in 2021, though during 2010, it was the most climate-vulnerable country (Eckstein et al., 2021; Rahaman et al., 2019a). Bangladesh has been identified as the most vulnerable to tropical cyclones, the third most vulnerable to sea levels rising in proportion to the number of people affected, and the sixth most vulnerable to floods in the entire globe (Francis and Maguire 2016; Rahaman et al. 2019b; Rahaman and Rahman, 2020). The irregular and unpredictable nature of rainfall and temperature is also increasing in Bangladesh (Rahaman and Rahman, 2020). All models and predictions also indicate that the changing nature of the climate and weather variability will impact the lives and livelihoods of the country's people. The projected climate change scenarios of Bangladesh are discussed in Table 1. 
Table 1. Projected future climate change scenarios of Bangladesh.

Variable Predicted Condition

Temperature According to the IPCC (2000) Special Report on Emissions Scenarios (SRES), the global mean surface temperature has already risen by 0.74 degrees Celsius over the last century, with an additional 0.2 degrees Celsius expected per decade (SRES). Temperature projections for Bangladesh:

- The average monsoon maximum and minimum temperatures show an increasing trend annually at $0.05^{\circ} \mathrm{C}$ and $0.03^{\circ} \mathrm{C}$, respectively (Rahman and Alam, 2003).

- Average winter season maximum and minimum temperatures show a decreasing and an increasing trend annually at $0.001^{\circ} \mathrm{C}$ and $0.016^{\circ} \mathrm{C}$ (Rahman and Alam, 2003).

- Global Circulation Model (GCM) predicts an average temperature increase of $1.0^{\circ} \mathrm{C}$ by $2030,1.4^{\circ} \mathrm{C}$ by 2050 and $2.4^{\circ} \mathrm{C}$ by 2100 (Agrawala et al., 2003).

Rainfall The average yearly rainfall in the country is around $2300 \mathrm{~mm}$, but there exists a broad spatial and temporal dispersion. Annual rainfall ranges from $1200 \mathrm{~mm}$ in the extreme west to over $5000 \mathrm{~mm}$ in the east and northeast (MPO, 1991). Projected rainfall pattern for Bangladesh:

- The precipitation will increase between 6 to $12 \%$ during monsoon months in 2030 and 2100 , respectively, while small decreases in the winter months also predict (Agrawala et al., 2003).

- A remarkable change in the duration of the rainy season is observed.

- Duration of the rainy season has been decreased (GoB, 2005).

- Heavy rain is occurring within a short period

Sea level rise The IPCC third assessment report (IPCC, 2001) predicted that the global rise in sea level from 1990 to 2100 would be between 9 and $88 \mathrm{~cm}$. Anticipated changes in global sea-level rise include:

- Under higher emission scenarios, sea-level rise since 2020, 2050 and 2080 are 6, 27 and $62 \mathrm{~cm}$, respectively (IPCC, 2001).

- The relative sea-level rise in the coastal areas of Bangladesh is 1-2 $\mathrm{mm} / \mathrm{year}$ (IPCC, 2001).

Salinity intrusion

- It is found that five ppt isohaline (line of equal salinity level) intrude more than $70 \mathrm{~km}$ landward in the westerly portion of the Sundarbans (GoB, 2005).

- During the dry season, deep landward intrusion occurs through various inlets in the western part of the coastal zone and Meghna Estuary (GoB, 2005).

- Sea level rise of $27 \mathrm{~cm}$ causes a $6 \%$ increase of brackish water area (GoB, 2005).

- Approximately an additional area of 327,700 ha would become a high saline water zone ( $>5 \mathrm{ppt}$ ) during the dry season due to a $60 \mathrm{~cm}$ sea-level rise ( $\mathrm{GoB}, 2005)$.

- In the monsoon, about $6 \%$ of freshwater areas (276,700 ha) will be lost 
(GoB, 2005).

Extreme It has been shown from the past three decades records that the frequency of climatic Events natural disasters has increased over time. It is predicted that the intensity and frequency of extreme climatic events will change faster than average, e.g., more floods and droughts, more tornadoes and tropical cyclones, and so on (GoB, 2005).

\subsection{Understanding of Loss and Damage}

Mitigation and adaptation efforts are now unlikely to effectively avoid the adverse effects of current and future climate change (Dow et al., 2013). In this perspective, poor and marginalized nations argue that the existing mitigation and adaptation approach is insufficient and calls for a third international climate change mechanism for dealing with residual impacts or 'loss and damage (L\&D)' (Huq et al., 2013; James et al., 2014). In 1991, the L\&D concept was first introduced in the global climate-change negotiations, when Vanuatu proposes international insurance provisions to compensate small developing island states for sea-level rise. Inevitably, this suggestion was denied, but the word insurance was included in Article 4.8 (Huq et al., 2013). Finally, the United Nations Framework Convention on Climate Change (UNFCCC) responded to these demands in 2013. The Warsaw International Mechanism (WIM) was set up to deal with the loss and damage to developing nations caused by the consequences of climate change.

Unfortunately, the UN climate regime has not yet defined L\&D. However, the phrase "L\&D" in the literature has been suggested that two categories of harm are recognized. One type includes permanent damage or irreversible 'loss,' such as the loss of land mass due to rising sea levels. The second category comprises reparable or recoverable 'damage,' such as storm-damaged shorelines (Doelle and Seck, 2020). Another way of distinguishing the concept of L\&D is between economic and non-economic L\&D and slow-onset and rapid or extreme weather events. Recently, a more controversial type of $L \& D$ is being discussed widely among scientists and negotiators, which is the damage from climate change response measures, such as efforts to mitigate, adapt and geo-engineering (Doelle and Seck, 2020). Therefore, the concept for L\&D is a newer agenda in the international climate change regime. But, without any doubt, it can reshape existing efforts to mitigate and adapt to climate change, but leadership from developed countries is needed for this (Huq et al., 2013).

\subsection{Understanding of Hailstorm and Related Loss and Damage}

The increasing frequency and intensity of natural disasters due to climate change have negatively impacted the lives and livelihood of Bangladesh's poor and marginalized people, including the farmer's community. The country is facing changing pattern of the climatic system, appears as uneven and untimely disasters, increasing loss and damage. In recent years, severe hailstorms and erratic rainfall patterns are observed in Bangladesh, with rapid-onset disasters but low exposure considering government response and media attention. These two extreme events are causing severe loss and damage to the life and properties of the marginalized group of people in Bangladesh.

There is much uncertainty about the effects of anthropogenic climate change on the frequency and severity of small-scale, sudden onset weather phenomena like hailstorms and subsequent loss and damage. However, several studies indicate that an apparent strong relationship exists 
between hailstorms activity and hailstorm damage. This relation intimates that hailstorms damage may increase in the future if global warming drives to further temperature increase (Botzen et al., 2010). In addition, human-induced climate change may result in the redistribution of rainfall and change in rainfall patterns such as heavy rainfall in a shorter period (Putnam and Broecker, 2017). Climate-resilient agriculture and crop production system is the key to sustaining a country's growth and economy. Therefore, with increased exposure to weatherrelated disasters like flood, flash flood, river erosion, salinity ingress, cyclone, etc., the agriculture sector should be the first to introduce risk transfer mechanisms. However, currently, there is no such scheme, from both public and private agencies, to support farmers in getting back at least some of their incurred loss they face almost every year by extreme weather events like hailstorm (Rahman, 2018).

\subsection{Hailstorm: A Nightmare for Smallholder Farmers}

In the last decade, poverty reduced significantly in Bangladesh, but in the Kurigram district, poverty is increasing. According to the 'Household Income and Expenditure Survey (HIES)2016' published by the Bangladesh Bureau of Statistics (BBS), 70.87\% of the population of this district live below the poverty line (BBS, 2016), whereas $63.67 \%$ was impoverished in the year 2010 (BBS, 2010). The economic activities of the district are primarily dependent on agriculture (70.41\%) and related livelihood activities (BBS, 2001; 2007). Therefore, if the agriculturerelated economic activities are somehow impeded, it will affect the livelihood of the people living in this district and, of course, their well-being. In recent days hailstorm has become an increasing threat for the poor people of this district as this sudden extreme event has adversely damaged the agriculture sector in northern parts of Bangladesh.

In March 2018, a hailstorm left the paddy fields, vegetable, trees and houses in Phulbari Upazila of Kurigram district devastated. More than $30 \%$ of agricultural lands were affected in the entire Upazila with damage to Boro crops as well as the devastation of mango, lychee, corn and other vegetable lands, which caused losses of several hundreds of thousands of US Dollars (DhakaTribune, 30 March 2018; BanglaTribune, 30 March 2018). "All our paddy fields have collapsed by the hailstorm, what will farmers eat if there is no yield!" told a 45-year-old farmer, Mr. Manu Mia, of the Kashipur Union of the Upazila. Due to the hailstorm, the entire rice field was destroyed, which had a land area of 0.40 acres. The same scenario was for many other farmers within this Upazila (BanglaTribune, 30 March 2018). The Department of Disaster Management (DDM) reported that the hailstorm event in March 2018 caused the death of one man, injury of 139 people, damage of 632 houses, and destruction of more than 1,291 hector croplands across the country (DDM, 2018). The impact of such a sudden extreme event has fallen heavily on the poorest people of the poorest district in the country's northern region.

Though there is no apparent countrywide trend in the frequency of events, they tend to spread northward from the central region of Bangladesh due to changing the climate (Yamane et al., 2010). These types of events are reasonably covered by news and reports in the national and local news media. The heightened degree of media coverage reveals that the frequency and severity of this rapid or sudden onset but low-exposed disasters have increased at an alarming rate in Bangladesh in the last few years. Nonetheless, the issues come to the surface just after the event. A follow-up investigation and assessment on the long-term impacts are not conducted. Also, the loss and damage (L\&D) of hailstorm event is a less explored issue. These unusual 
weather events are causing loss and damage to the life and properties of millions of people in Bangladesh. But, no evidence of adequate support was visual from both the government and nongovernment disaster relief agencies in response to the disasters like a hailstorm. In addition, these types of disasters are not covered by government safety net programs.

This study explored the potential impacts of sudden onset but low-exposed disasters, particularly hailstorm and associated impact in the climate-vulnerable northern part of Bangladesh. The study's overall goal is to evaluate the long-term implications of sudden onset but low exposed disasters on the climate-sensitive economic activities of the week and marginalized people living in Bangladesh's northern parts. Therefore, firstly, the study measured the immediate financial and non-economic loss and damage caused by low exposed disasters such as hailstorms on livelihood and economic activities such as farming. Secondly, this study attempted to assess the longer-term impacts of such extreme events on human well-being. This study has also measured the responses and support from the government and non-government agencies and finally forwarded recommendations to deal with such disasters and ensure immediate and planned actions to reduce the loss and damage.

\section{Methods}

\subsection{Study Area}

Phulbari Upazila (Figure 1), under the Kurigram district having an area of 163.63 sq. km, is located in between $25^{\circ} 32^{\prime}$ and $26^{\circ} 04^{\prime}$ north latitudes and in between $89^{\circ} 28^{\prime}$ and $89^{\circ} 40^{\prime}$ east longitudes. The West Bengal state of India bounds it on the north, Kurigram Sadar, Rajarhat and Lalmonirhat Sadar Upazilas on the south, Nageshwari Upazila on the east, Lalmonirhat Sadar Upazila on the west. The primary income sources of the residents are agriculture $(74.28 \%)$, nonagricultural labourer (5.18\%), and commerce (9.31\%) (BBS, 2007). 


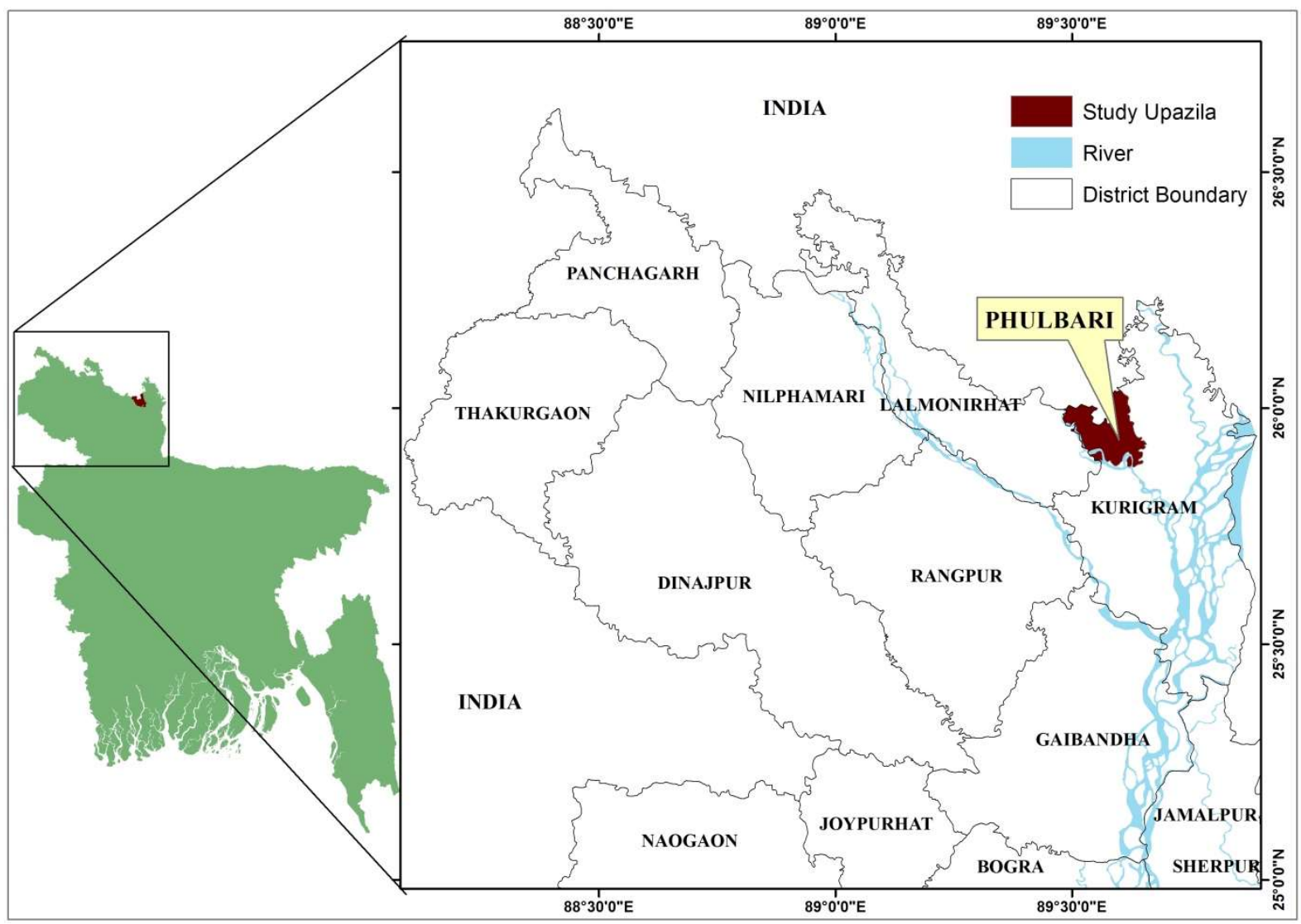

Figure 1. Study Area (Phulbari Upazila of Kurigram District)

\subsection{Data Collection}

The study adopted a research method that compares both qualitative and quantitative investigation procedures. The qualitative part was anchored in 08 Participatory Vulnerability Analysis (PVA) (01 from each Wards), 05 Key Informant Interview (KII) and the case study method. On the contrary, quantitative data had collected through conducting the sample questionnaire survey. A set of questions and checklists had developed based on existing literature reviews, analysis of the study proposal, and frequent consultation with relevant experts. This study used data from a questionnaire administered to inhabitants of eight wards (Anantapur 01, Anantapur 2, Anantapur 3, Kashipur 4, Kashipur 5, Dharmapur 6, Ajoatari 7, and Ajoatari 8) of Kashipur Union under Phulbari Upazila of Kurigram district. The agriculture farmers of Kashipur union under Phulbari Upazila were affected by the hailstorm event on 30 March 2018. However, the secondary information had collected through literature review, historical data analysis from the Bangladesh Meteorological Department (BMD), published and unpublished scientific journals and media reports, etc. The field visit had conducted during the month of October 2018 (Figure 2). 


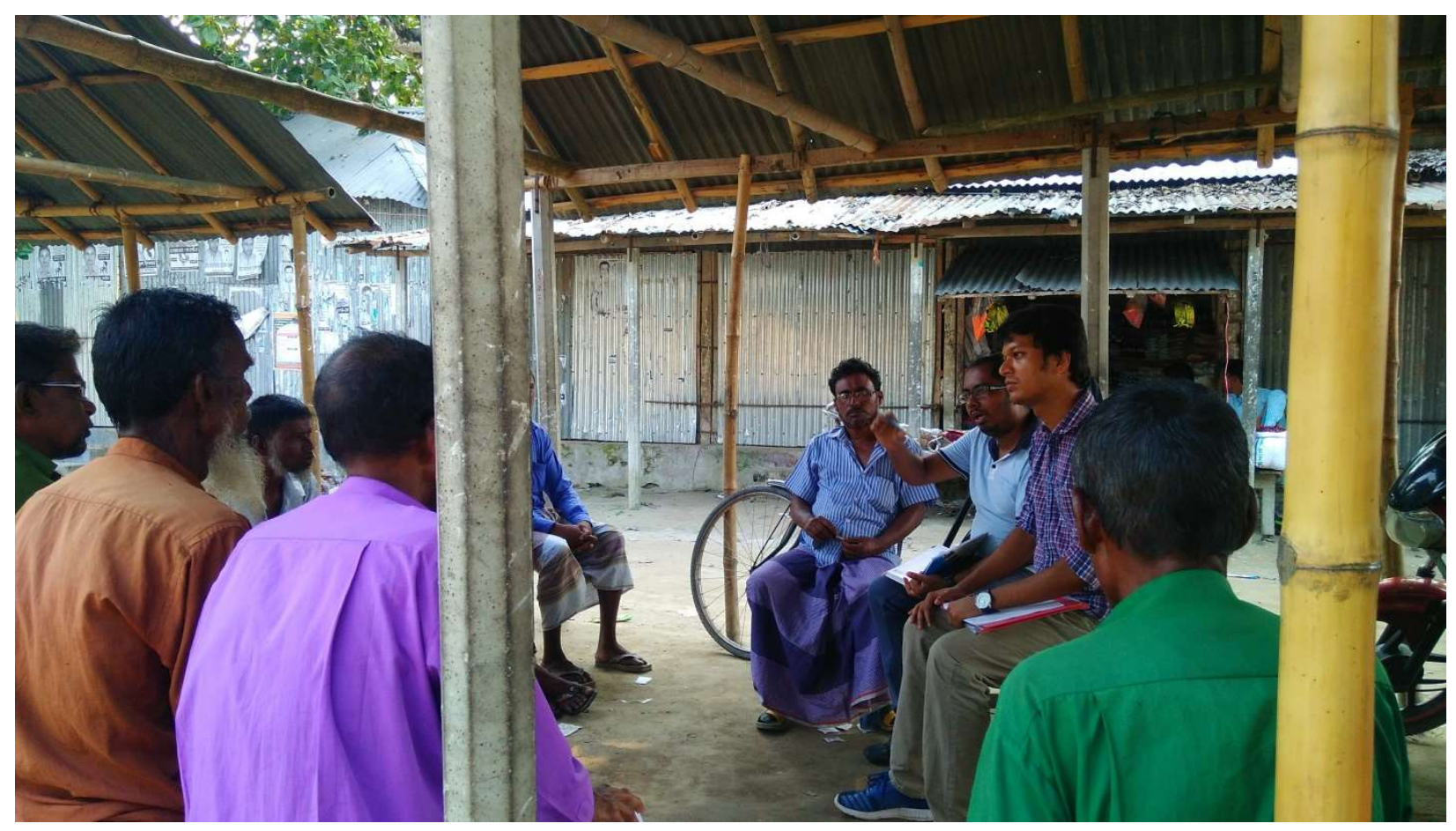

Figure 2. Field visit for data collection.

\subsection{Data Analysis}

A simple random sampling (also referred to as random sampling) method was applied to investigate the targeted population. This method is used when the whole population is accessible, and the investigators have a list of all subjects in this target population (Elfil and Negida, 2017). A total of fifty respondents were interviewed for this study, all of whom were household heads. These respondents were selected randomly from a list of 250 hailstorm affected households developed by the Phulbari Upazila Parishad. If the randomly picked farmer was unable to be interviewed at the time of data collection, the next available farmer on the list was interviewed. The study included both questions that were open and closed. In October 2018, the survey had carried out. IBM SPSS Statistics version 21 was used to analyze the data. The analysis was carried out in two stages. Firstly, the information was tabulated in SPSS software, and then frequency distribution and percentage had calculated. Finally, descriptive analysis, including both textual and tabular formats, described the study results. Respondents were asked about their age, ownership of the house and agricultural land, access to electricity, livelihood source, experience on natural hazards, loss and damage, available adaptation and coping choices, etc. The overall goal was to investigate the impact of various rapid onset extreme climatic events on the livelihood of marginalized farmers.

\section{Results and Discussion}

\subsection{Demographic and Socioeconomic Profile of Respondents}

Table 2 shows the respondent's chosen demographic and socioeconomic features. The age ranged from 18 to 75 years. The distribution pattern indicates that all age groups, youth, the elderly, and the middle-aged, engage in agricultural activities, such as paddy and vegetable farming. 
Although few respondents were women (12\%), most participants in the survey were male (88\%). The ratio indicates that men mainly participate in agricultural production and are the head of households. As head of the household, the male usually decides on family matters. The interviewees stayed in their own home $(100 \%)$, mainly in the tin-shade house $(88 \%)$. Only half of respondents have electricity access $(50 \%)$. Studies have shown that the highest proportion of respondents (42\%) used the national grid as a primary electricity source. Another $6 \%$ use solar, and the remainder $50 \%$ are without access to electricity. The primary occupation is paddy $(60 \%)$ and vegetable (16\%) cultivation. Livestock rearing (8\%), fisheries $(2 \%)$ and mixed job (14\%) are also supportive income generation activities (IGA) found among the respondents. The primarily grown crops in this area are paddy (64\%) and vegetables (24\%). People cultivate mainly crops on borrowed (52\%) and own (22\%) land, and simultaneously a good share of the respondents grown in leased $(10 \%)$ and shared $(8 \%)$ lands.

Table 2. Demographic and Socioeconomic Profile of Respondents.

\begin{tabular}{|c|c|c|}
\hline Characteristic & Number & Percentage \\
\hline \multicolumn{3}{|l|}{ Age (In Years) } \\
\hline $18-30$ & 10 & 20 \\
\hline $31-40$ & 10 & 20 \\
\hline $41-50$ & 15 & 30 \\
\hline $51-60$ & 10 & 20 \\
\hline$>60$ & 6 & 10 \\
\hline \multicolumn{3}{|l|}{ Gender } \\
\hline Male & 44 & 88 \\
\hline Female & 6 & 12 \\
\hline \multicolumn{3}{|l|}{ Is the respondent Household-Head? } \\
\hline Yes & 49 & 98 \\
\hline No & 1 & 2 \\
\hline \multicolumn{3}{|l|}{ Do you own the house you live in? } \\
\hline Yes & 50 & 100 \\
\hline No & 0 & 0 \\
\hline \multicolumn{3}{|l|}{ Type of the living house } \\
\hline Jhupri (Hut) & 2 & 4 \\
\hline Kacha (Mud-built house) & 2 & 4 \\
\hline Semi-Paka (Semi building) & 0 & 0 \\
\hline Tin Shade & 44 & 88 \\
\hline Paka (Building) & 2 & 4 \\
\hline \multicolumn{3}{|l|}{ Access to electricity } \\
\hline Yes & 25 & 50 \\
\hline No & 25 & 50 \\
\hline \multicolumn{3}{|l|}{ Source of electricity } \\
\hline Power Grid & 21 & 42 \\
\hline Solar & 3 & 6 \\
\hline Both & 1 & 2 \\
\hline
\end{tabular}


Major income source

No electricity $25 \quad 50$

$\begin{array}{lll}\text { Paddy Farming } & 30 & 60\end{array}$

Others

\begin{tabular}{cccc} 
& Livestock & 4 & 8 \\
& Vegetable & 8 & 16 \\
Fisheries & 1 & 2 \\
Major crops & Mixed profession & 7 & 14 \\
Others & Paddy & 32 & 64 \\
& & & \\
Type of salt cultivated land & 12 & 24 \\
& Own & 6 & 12 \\
Sharecropping (Dhar kore) & & 22 \\
Lease (Ijara) & 11 & 8 \\
Borrowing (Borga) & 4 & 10 \\
Community land (Somity) & 5 & 52 \\
Other & 26 & 0 \\
\hline
\end{tabular}

\subsection{Major Climatic Stressors for the Farmers}

It is found that hailstorm (96.2\%), flood (80.8\%), drought $(73.1 \%)$, storm $(86.5 \%)$, and thunderstorm (3.8\%) are significant hazards in Phulbari Upazila of Kurigram district (Figure 3). Among these hazards, hailstorm (96.2\%), flood (80.8\%), drought (73.1\%), and storm (86.5\%) are the most catastrophic hazards. On the other hand, thunderstorm (3.8\%) is comparatively less destructive. All of the respondents $(100 \%)$ said that they had experienced the impact of hailstorms in their community. It is also observed that in the last ten years and five years number of hailstorm events increased significantly. Around $6 \%$ of respondents said it had raised a lot, $86 \%$ said it rose a bit. In the last ten years, 10 to 12 numbers hailstorm events were observed by the respondents $(48 \%)$; simultaneously, the number was 7 to 9 times in the previous five years $(56 \%)$. The last catastrophic hailstorm event was experienced in March in the year 2018. 


\section{Major natural hazards}

$\square$ Hailstorm $\square$ Flood $\square$ Drought $\square$ Storm $\square$ Thunderstorm

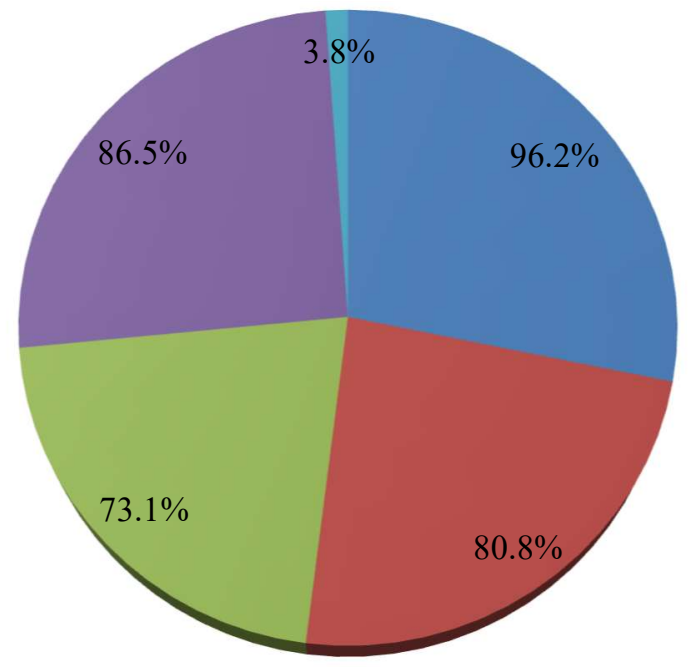

Figure 3. Major natural hazards in Phulbari Upazila.

\subsection{Long Term Impacts of Hazards including Hailstorm}

Natural hazards like hailstorms, flood, drought, storm, thunderstorm and cold wave, etc., have resulted in economic and non-economic loss and damages to the marginal agriculture farmers of Phulbari Upazila. The significant financial losses are damage of crops $(68 \%)$ and fruit gardens $(24 \%)$, loss of livestock (18\%), destruction of trees $(26 \%)$ and housing $(100 \%)$, and damage of household furniture (4\%) etc. (Figure 4$)$. At the same time, the non-economic losses are trauma and injury (6\%), a problem with children's education (42\%), and societal anxiety (2\%) (Figure 4). Those incidents have long term negative impacts on the life and livelihoods of the people. Figure 5 shows a hailstorm damaged crop field, and that event occurred during March 2018. 


\section{Imapcts of extreme natural events such as hailstorm}

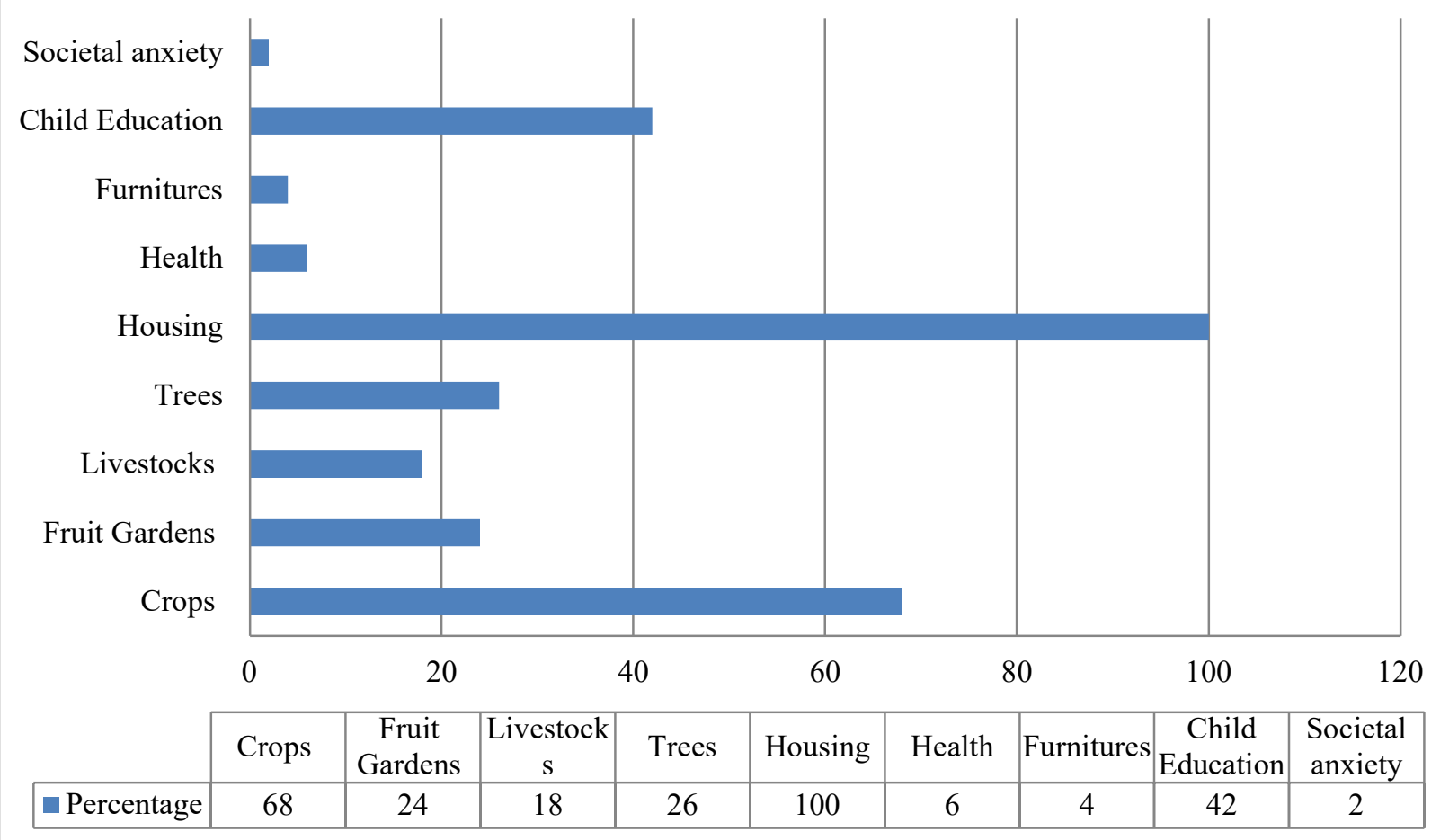

Figure 4. Long term impacts of hailstorm events in Phulbari Upazila. 


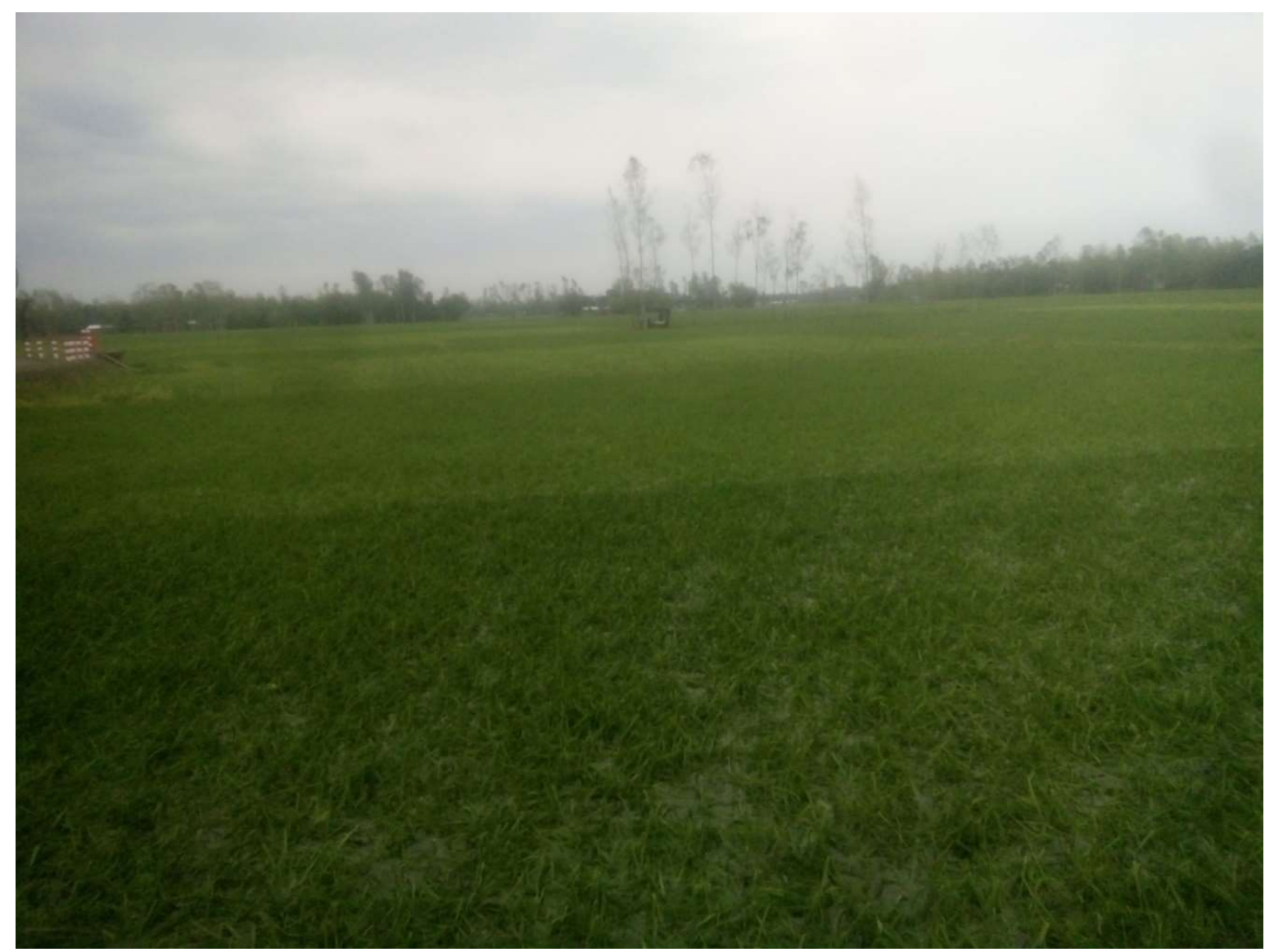

Figure 5. A hailstorm damaged a crop field in Phulbari Upazila.

Many farmers (68\%) have experienced more or less loss of crop production due to the hailstorm events. $14 \%$ of farmers said around 601-800 kilograms of paddy was damaged by a single hailstorm event which caused a loss of around BDT 8000-10000 (95-118\$) (12\%). Another 10\% of farmers said the loss was 1001-1200 kilograms of paddy. The highest amount of loss of paddy was 2201-2400 kilograms (2\%) with a single event of a hailstorm. The highest economic loss that emerged from paddy damage was identified as 350000 (4130\$) (2\%), $30000(350 \$)(4 \%)$ and 25000 (295\$) (4\%) BDT respectively. Fruits like mango (12\%), jackfruit (2\%), betel nut $(7 \%)$ and vegetables $(2 \%)$ were also damaged, which caused a financial loss in a range of BDT $1-2000(0.01-24 \$)$ to BDT 25000 (295\$). Livestock damage caused a loss of money within the extent of BDT $500(6 \$)(4 \%)$ to BDT 35000 (413\$) (2\%). Damage to trees caused a loss of BDT $500(6 \$)(10 \%)$ to $10000(118 \$)(4 \%)$. Almost all the roofs of the respondent's house's shelters and walls are made of the corrugated iron sheet (also called 'Dheutin' locally), nearly all of the house's roofs and walls were damaged by the hailstorm, which caused them an economic loss of BDT $5000(60 \$)(14 \%)$ to BDT $50000(590 \$)(8 \%) .20 \%$ of respondents said their children couldn't go to school for 7 to 9 days, and 16\% said it was 1-3 days. Few schools and Madrasa (religious schooling) building were also damaged (6\%). Around $44 \%$ of the interviewees had to sell their goods or savings or capital to address the loss due to the hailstorm.

From the year 2009 to 2014, hailstorm has affected households in almost all divisions of Bangladesh. The figure shows that Dhaka (20.86\%), Rangpur (16.62\%), Rajshahi (12.86\%), and 
Sylhet (12.54\%) division has the highest number of households affected by hailstorm hazard (Figure 6). Moreover, crops, houses, and homestead and forestry sectors faced the most remarkable economic damage, which encounters 9679.6 (114.19 million \$), 1386.53 (16.36 million\$) and 325.14 (3.84 million \$) million BDT of loss (Figure 7).

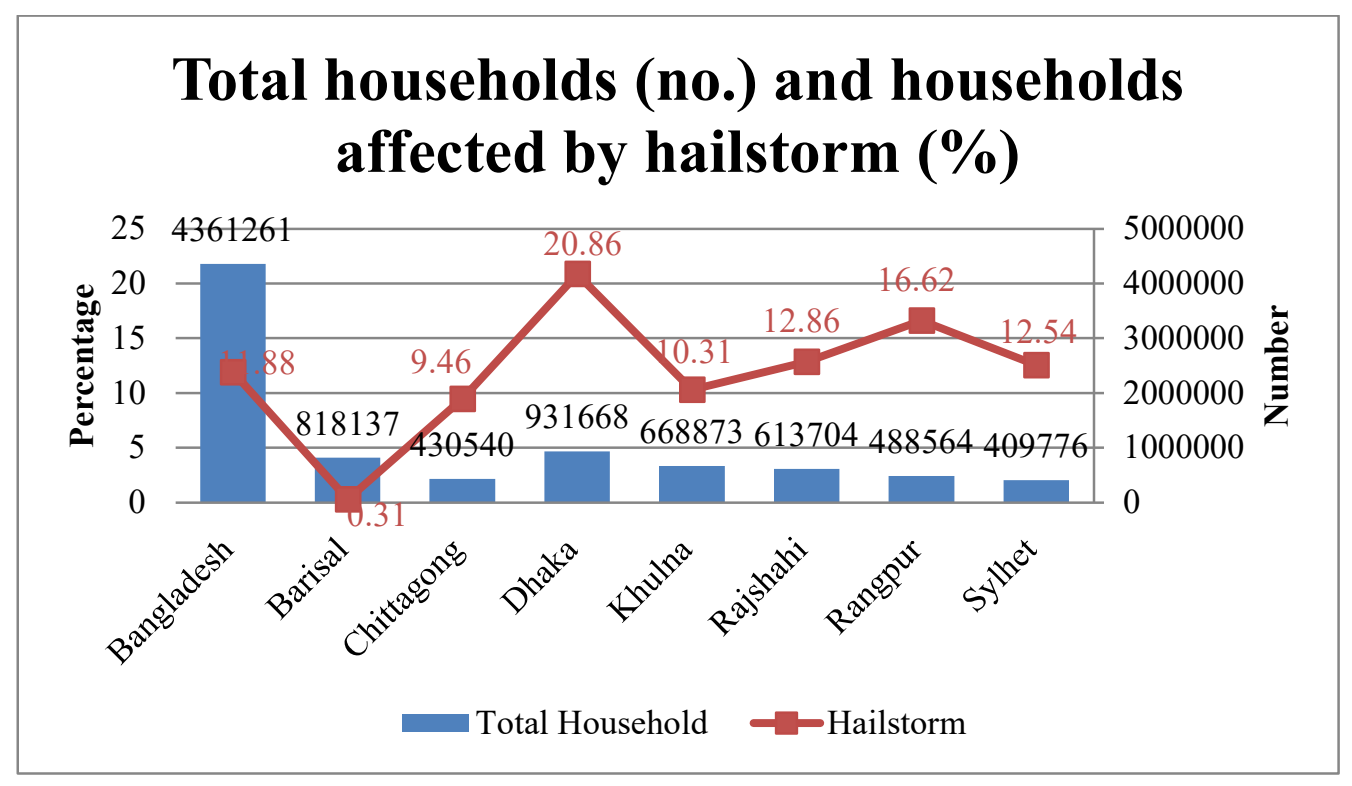

Figure 6. Distribution of hailstorm affected household by division from 2009 to 2014 (Based on data collected from BBS, 2015).

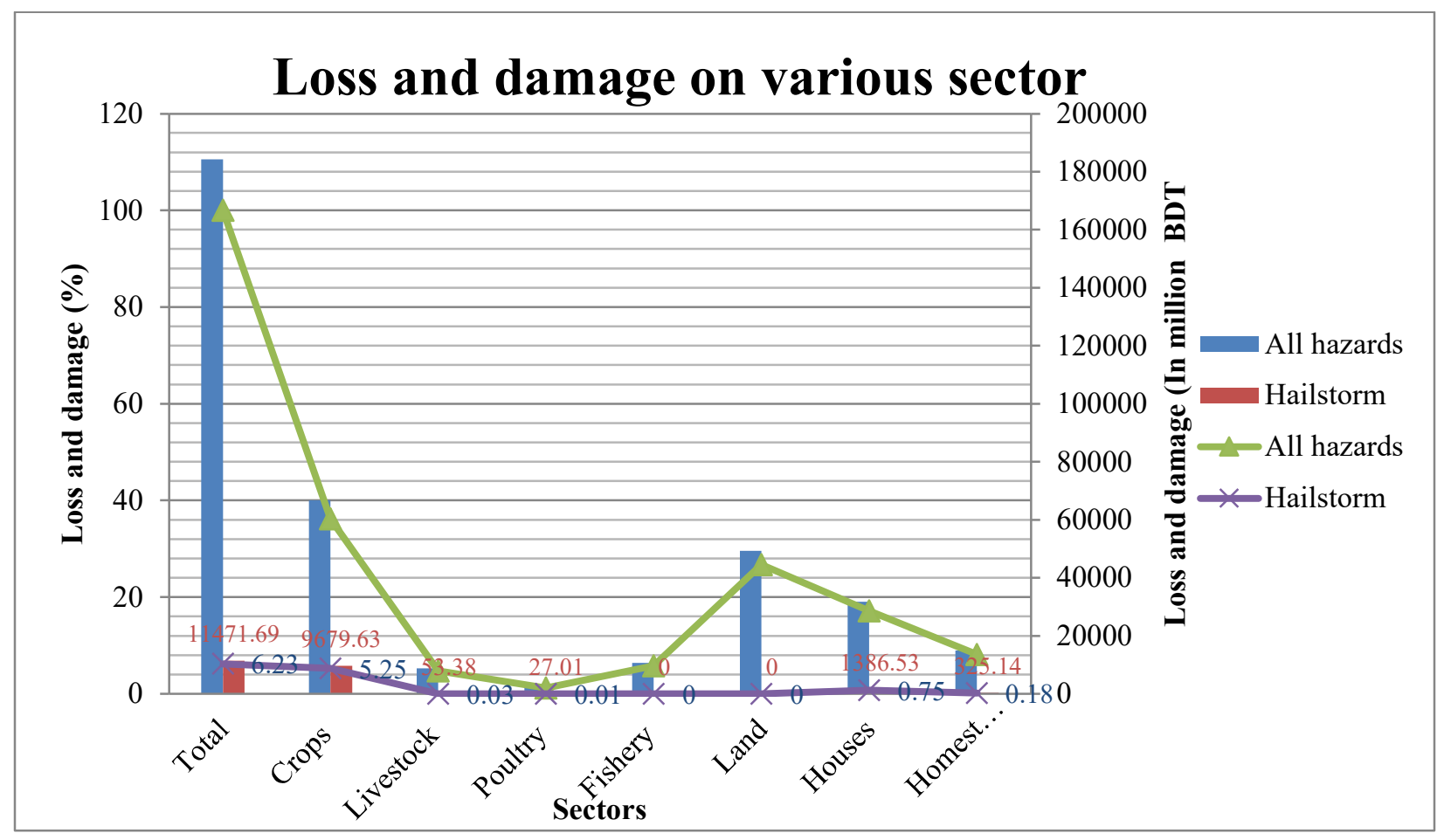

Figure 7. Distribution of household-level hailstorm induced loss and damage in different sectors from 2009 to 2014 (Based on data collected from BBS, 2016). 


\subsection{Existing Adaptive Measures}

Almost all (94\%) respondents said they had no adaptation options for extreme events like a hailstorm. Only a few $(6 \%)$ said they are using polythene on their house roof, but it's not working and not a practical solution (Figure 8).

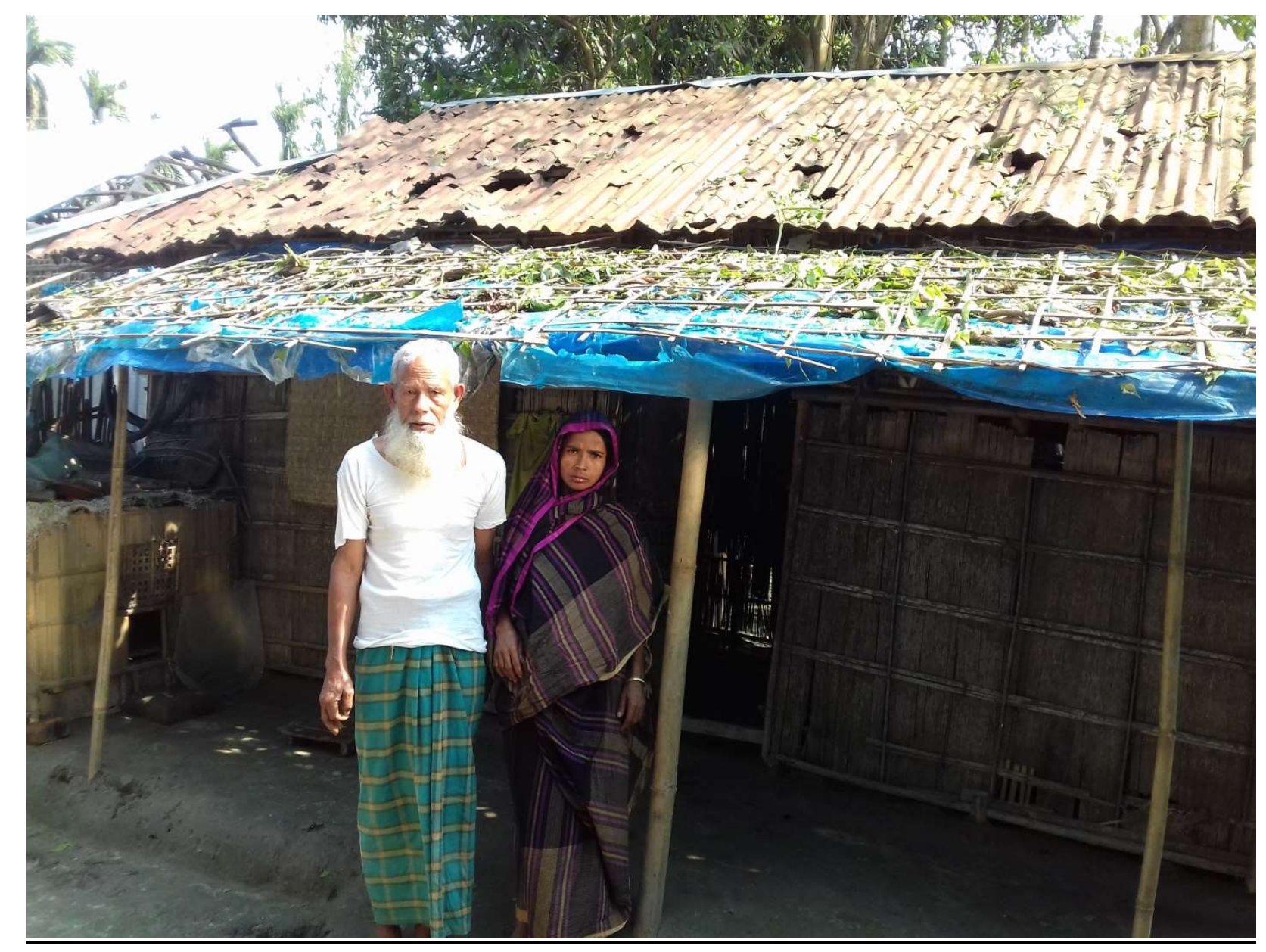

Figure 8. Respondents use polythene in their house roof as an adaptive measure against hailstorm.

All respondents $(100 \%)$ urged that the government or non-government organizations have not done anything to prevent the impacts of the hailstorm in their village. Moreover, none $(100 \%)$ has provided insurance or financial support, particularly for hailstorm event. The respondents expressed that the primary reasons that made them difficult to adopt effective measures to prevent the impacts of hailstorms are lack of money (26\%), lack of skills or knowledge (12\%), lack of resources $(6 \%)$, absence of insurance $(10 \%)$ and lack of government or private support (28\%). Moreover, most people $(48 \%)$ had no idea about preventive measures against the hailstorm, and many (36\%) said there was nothing else they could do (Figure 9). 


\section{Reasons for failing to adopt effective adaptive measures}

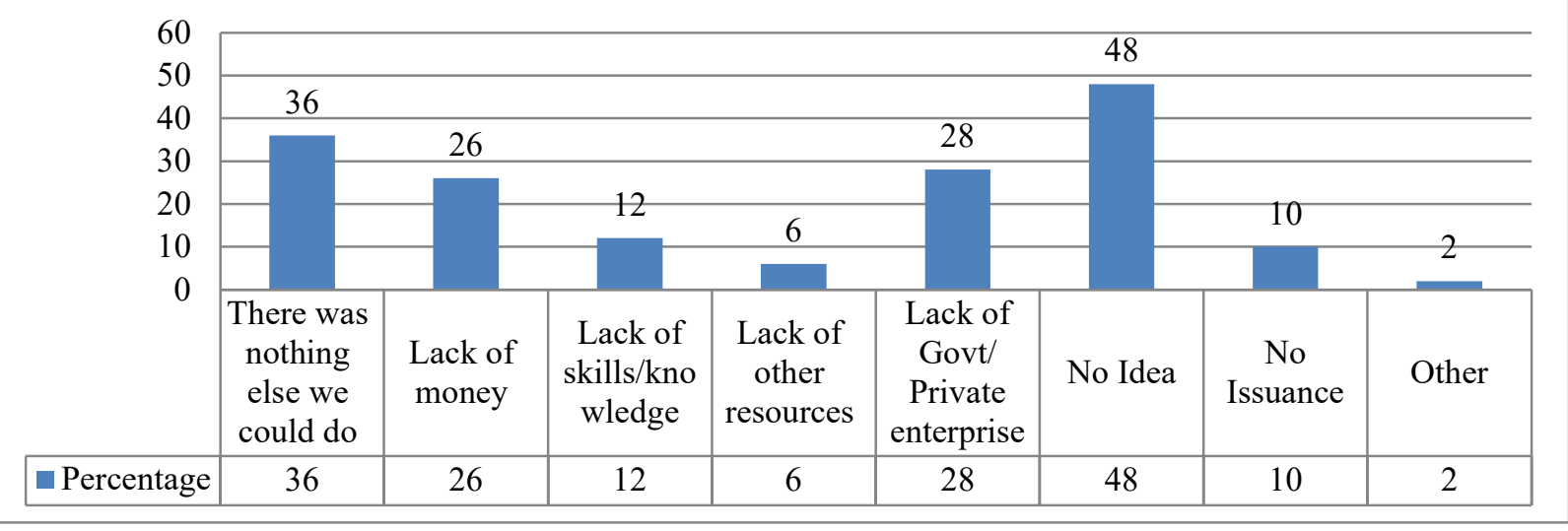

Figure 9. Major reasons for failing to adopt effective adaptive measures.

\subsection{Existing Coping Measures}

Coping options against the hailstorm were found very limited during the field investigation. Nonetheless, respondents used to do to cope with the adverse impact of hailstorm are relying on support from other people (38\%), getting a loan on high interest (money or in-kind) (44\%), selling properties (34\%), using buffers (e.g. stored food, savings) (10\%), earning extra income $(12 \%)$ and engaging in small business or work as day labor (4\%). For any support people, they mainly rely on relatives $(38 \%)$ and neighbors $(26 \%)$, and they receive food $(12 \%)$, money $(32 \%)$ and shelter (6\%) as support (Figure 10).

\section{Coping measures}

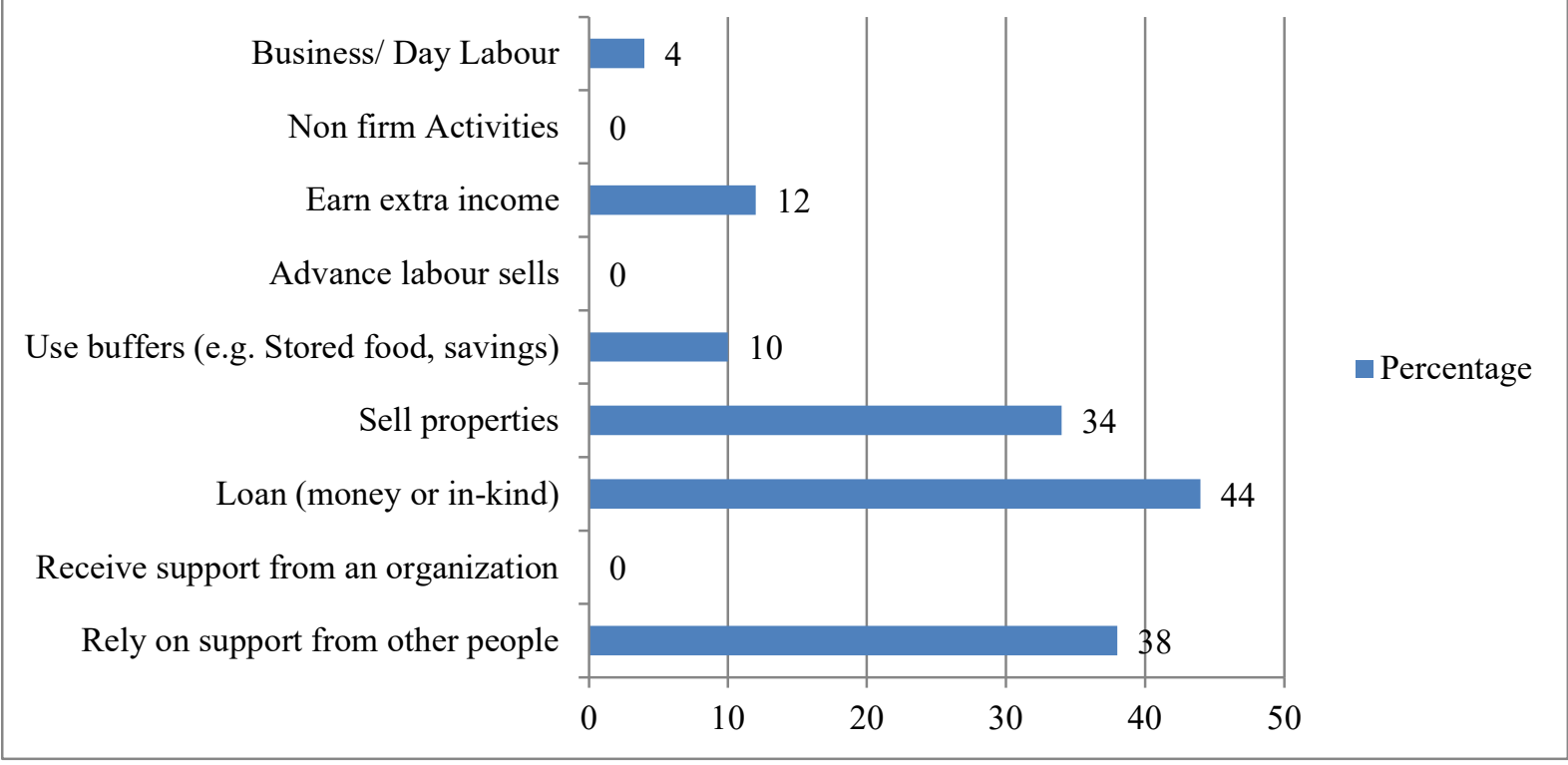

Figure 10. Key coping measures against hailstorm hazard taken by the stallholders. 
According to them, these are not fully effective, but in most cases, infrequently effective (24\%). However, the monetary loan is somehow compelling, which they receive from banks (e.g. Grameen bank) (4\%), NGO (e.g. BRAC, ASA) (30\%), cooperatives (2\%), local money lenders $(6 \%)$ and relatives $(2 \%)$. However, $4 \%$ of the respondents said they wouldn't pay back the loan; $10 \%$ had partly paid the loan, and $28 \%$ said they haven't paid it but hope to pay the loan. $18 \%$ found it fully effective, $10 \%$ found it essentially practical, and $12 \%$ found it marginally effective. People have also sold their land (6\%), livestock (e.g. cows, hens, ducks) (14\%), and trees (14\%) to cope up with the loss. However, it was not that effective. People are also involved with nonfirm activities such as day labor $(8 \%)$, auto-rickshaw driving $(2 \%)$ to add extra income to his family. The reasons behind failing to take any coping measures were lack of money $(66 \%)$, lack of skills or knowledge (52\%), lack of institutional support $(86 \%)$ and have no idea $(2 \%)$ what to do in such a situation (Figure 11). It is also observed that from 2009-2014, households received the most negligible percentage of early warning to cope with hailstorm damage in comparison to other disasters (Figure 12).

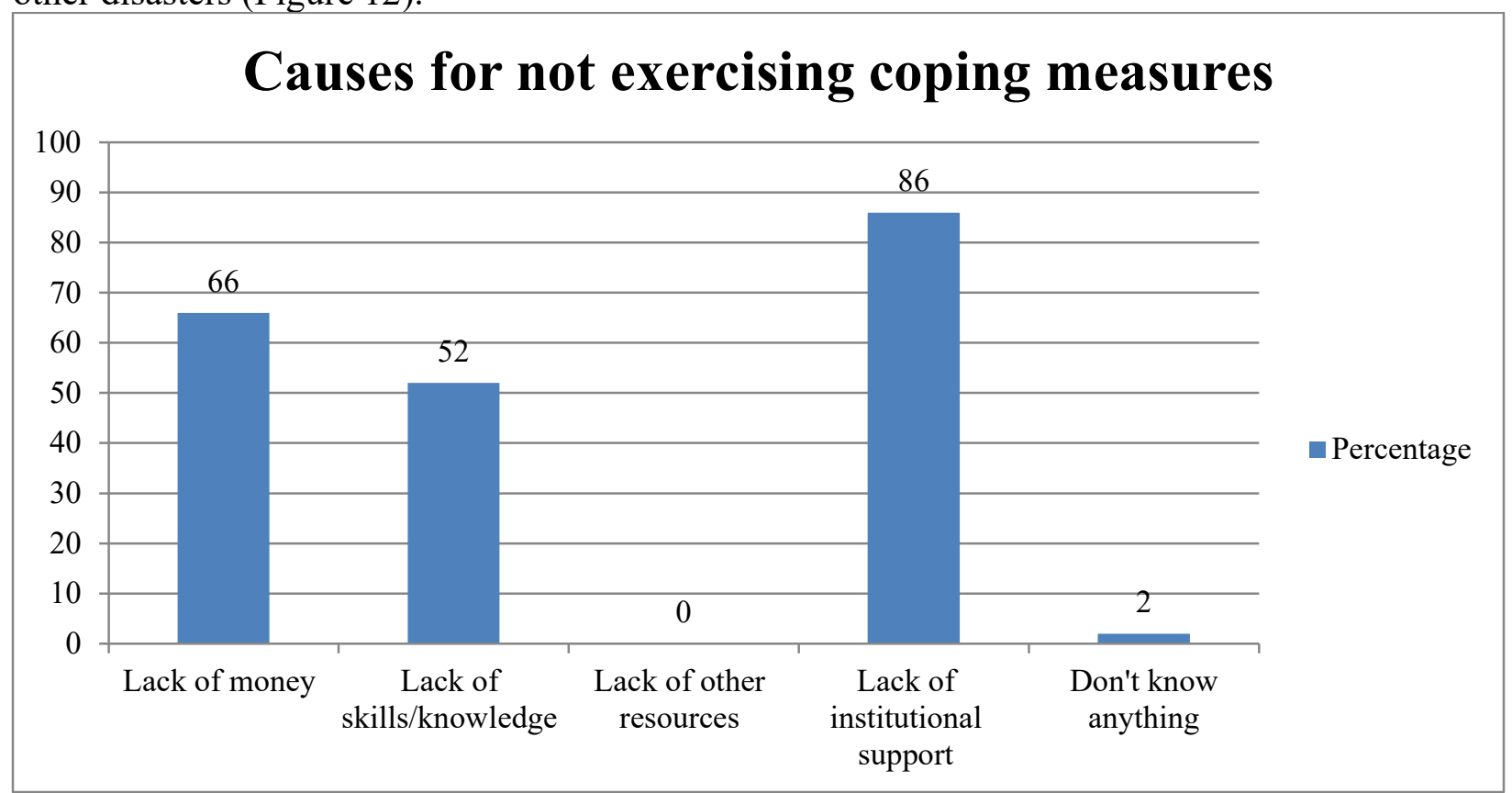

Figure 11. Key causes for not exercising any coping measures. 


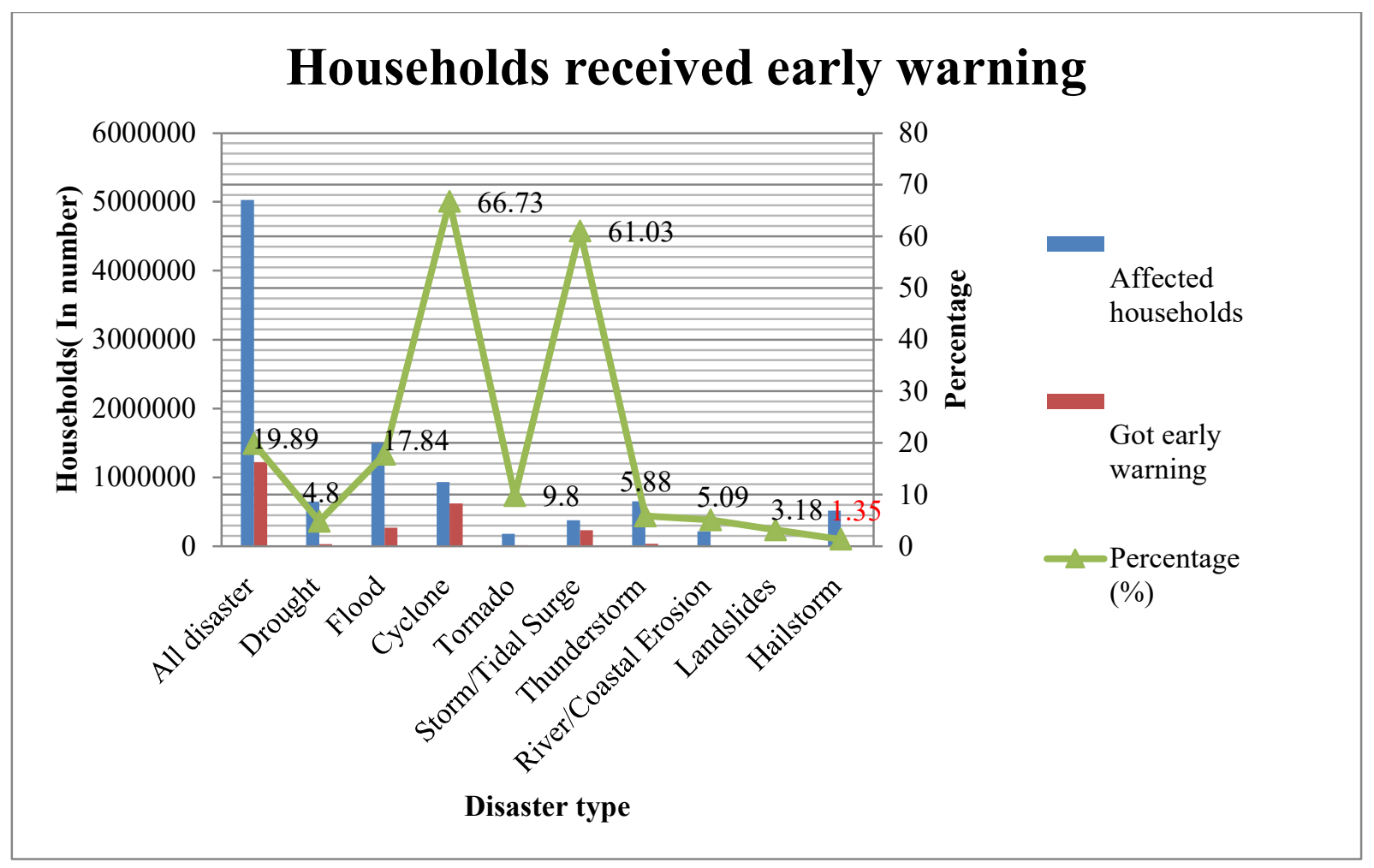

Figure 12. The distribution of hailstorm and other disaster-affected households received an early warning during the period of 2009 to 2014 (Based on data collected from BBS, 2016).

\subsection{Existing Supports from GOs/NGOs}

The respondents said they had not received any support from the government organizations (GOs) or non-government organizations (NGOs) to reduce the hailstorm impacts. Although the local government distributed some relief goods after the hailstorm, it was insufficient compared to the loss. People said corruption exists in the local government institutions, including the Union Parishad and Upazila Parishad. The Union members and chairmen often fail to send the actual situation report to the highest government officials. There is also a lack of proper willingness of the local government officials to help the affected people. Government officials often are bound to take insufficient measures as they do not get enough relief goods to support the affected community. Moreover, corruption and lack of transparency in the administrative process in the local government is another primary concern. It is found from field investigation various natural hazards have affected the trend of the cropping area. It is observed that in comparison to the year 2016-17, the per respondent's farming area has slightly reduced in the year 2017-18 in the study area (Figure 13). 


\section{Cultivativation area (In decimal unit)}

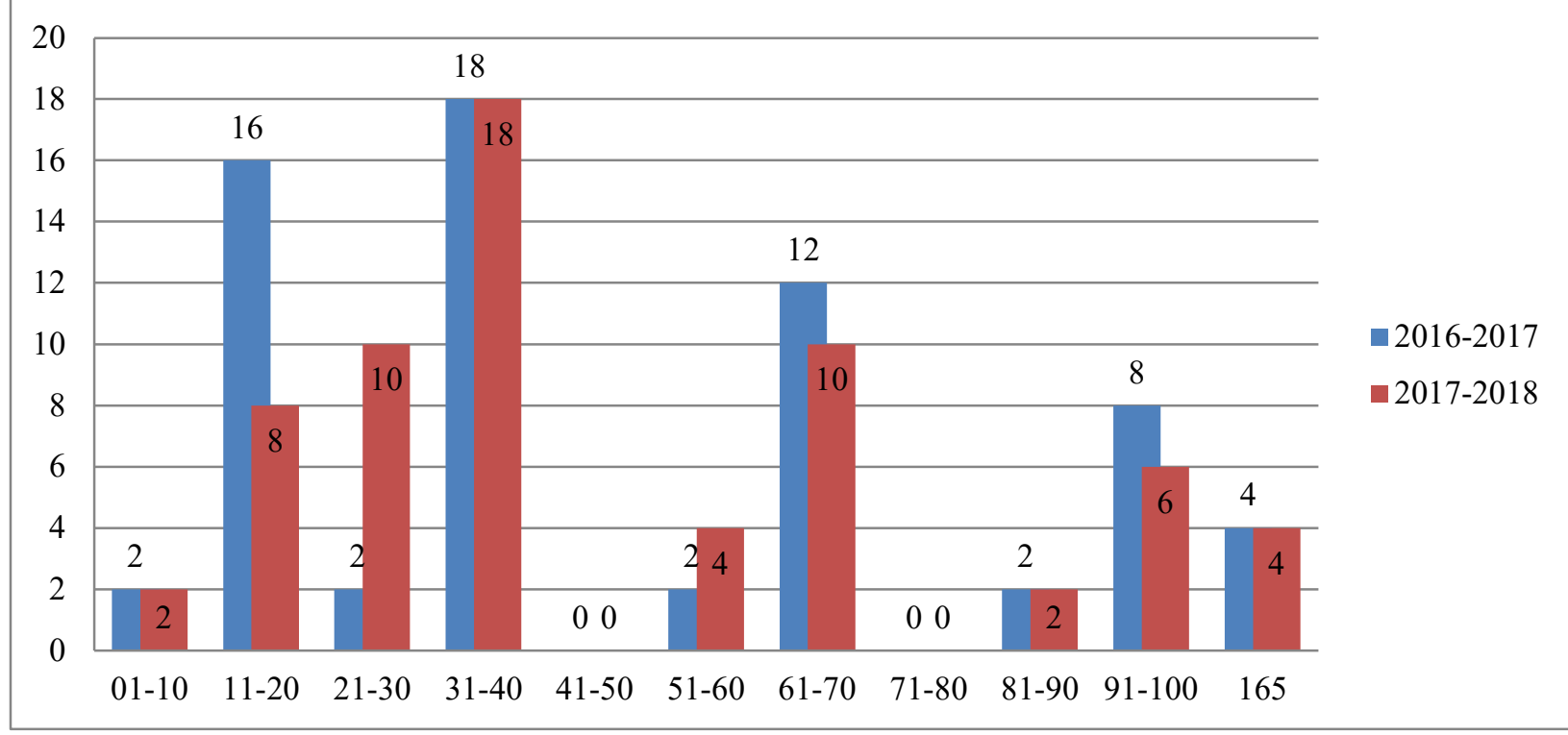

Figure 13. Trend of cultivation area per respondent for the year 2016-2017 and 2017-2018.

Post-disaster response for the hailstorm events was not visible at the local level. People told Union Parishad members and chairmen sometimes send incomplete or wrong information to the higher authority. They also often execute partiality in preparing the list of most affected households. There was also an absence of early forecasting and preparedness actions for such hazards. The house's structures are not strong as well. There is a need for building hailstorm resilient housing. People also thought that as it is a natural phenomenon, so it is unavoidable. There is a need for a comprehensive disaster management system for a particular disaster like a hailstorm. Initiatives from government and non-government organizations are essential. There is also a need for rehabilitation measure for the affected households.

\section{Disaster Management and Climate Change Adaptation Planning in Bangladesh}

Bangladesh has made notable progress in developing strategies and policies for comprehensive disaster management and climate change adaptation (CCA). But over time, it has become imperative to update and link the existing approaches to introduce effective disaster management, risk reduction and adaptation planning that can address loss and damage (L\&D) associated with climate change-induced extreme natural events, including hailstorm. Although hazards like a hailstorm have significant economic and non-economic impacts on the life and livelihoods of a marginalized group of people like the smallholder's farmers community, these disasters related damages are not often effectively addressed in the present policies. The rapid onset disasters like hailstorm also have a comparatively lower concentration from government administrative authority, relief agencies, press and media. So, a paradigm transformation is essential in the current disaster management, risk reduction and CCA planning in Bangladesh, which also addresses climate change-induced loss and damages intending to make the country resilient against disaster-related loss and damage. 


\subsection{National level Policy, Planning on disaster management and CCA}

With a vision to build a disaster and climate-resilient country, the Government of Bangladesh (GoB) established the Disaster Management Bureau (DMB) in 1993. It has also developed the Standing Orders on Disaster (SOD) in 1997, National Plan for Disaster Management (20102015) and revised Standing Orders on Disaster (SOD) in 2010 and 2019. The Disaster Management Act had enacted in 2012. One of the significant steps under this act is to reconstruct the Directorate of Relief and Rehabilitation into the Department of Disaster Management with more extensive obligation. A disaster management regulatory framework is built under which the Bangladesh Disaster Management Framework is implemented, and in which work of Ministries, Departments, non-government organizations (NGOs) and civil society organizations (CSOs) are undertaken (Bijoy and Chakraborty, 2013). The country also developed Cyclone Shelter Construction, Maintenance and Management Policy (2011) in 2012, National Disaster Management Policy (2015) in 2016, National Plan for Disaster Management (2016-2020) in 2017 and National Plan for Disaster Management (2021-2025) in 2020 to take appropriate disaster management and contingency plan to build a resilient nation.

Considering climate change adaptation (CCA) and the people's potential welfare, climate change is a major glowing threat to national development identified by the Government of Bangladesh (GoB). Therefore, to overcome this deteriorating situation, the government formulated the National Adaptation Programme of Action (NAPA) in 2005, the Bangladesh Climate Change Strategy and Action Plan (BCCSAP) in 2009 and established the Bangladesh Climate Change Trust Fund (BCCTF) to progress the efforts under BCCSAP (Rahaman and Rahman 2020). In addition, to this, the country has also developed other national policies and strategies, including Intended Nationally Determined Contributions (INDCs) (2015), the National Sustainable Development Strategy (NSDS) 2010-2021 (2013), the Perspective Plan 2010-2021 and 20212041 (Vision 2021 and 2041), and Eighth Five-Year Plan (2020) and National Adaptation Plan (NAP) (In progress).

\subsection{Gaps in Disaster Management and CCA Policy and Planning}

The Bangladesh government has developed a regulatory framework for disaster management under the Standing Orders on Disaster (SOD) in 1997, which was later updated and revised in 2019. In connection with the transition from a reactive approach to a proactive one, the legal framework for disaster risk management in Bangladesh has been established and reviewed by incorporating various disaster risk management programs. This regulative framework sets the appropriate legislative, policy, and best-practice framework to address disaster risk reduction and emergency management activities in Bangladesh (MoDMR, 2019). The framework comprises of following: 
Table 3. Components of regulatory framework for disaster management in Bangladesh (Adapted from MoDMR, 2019)

\begin{tabular}{|c|c|}
\hline Component title & Objectives \\
\hline a) Disaster Management Act 2012 & $\begin{array}{l}\text { - To develop the legislative framework for } \\
\text { disaster and emergency management. } \\
\text { - To serve as a legal basis for the } \\
\text { management of activities and actions. } \\
\text { - To impose legal obligations on Ministries, } \\
\text { committees, and appointments. }\end{array}$ \\
\hline b) National Disaster Management Policy 2015 & $\begin{array}{l}\text { - To define the national perspective on } \\
\text { disaster risk reduction and emergency } \\
\text { management. } \\
\text { - To designate the strategic framework and } \\
\text { national principles of disaster management. }\end{array}$ \\
\hline $\begin{array}{l}\text { c) National Plan for Disaster Management } \\
2016-2020\end{array}$ & $\begin{array}{l}\text { - To serve as a strategic document that will } \\
\text { be effective for a set period of time. } \\
\text { - To act as a master plan which provides } \\
\text { guidance in the overall preparation and } \\
\text { implementation of responsibilities for } \\
\text { relevant sectors and disaster management } \\
\text { committees at all levels. }\end{array}$ \\
\hline d) Standing Orders on Disaster- SOD 2019 & $\begin{array}{l}\text { - To outline the duties and responsibilities of } \\
\text { all committees, Ministries, and other } \\
\text { organizations in the DRR and emergency } \\
\text { management operations. } \\
\text { - To ensure that all parties involved } \\
\text { understand and carry out their roles and } \\
\text { responsibilities in disaster management at } \\
\text { all levels. }\end{array}$ \\
\hline e) Best Practice Models & $\begin{array}{l}\text { - To provide guidelines and best practice } \\
\text { models for Ministries, NGOs, disaster } \\
\text { management committees, and civil society } \\
\text { involved in disaster risk management } \\
\text { implementation. }\end{array}$ \\
\hline
\end{tabular}

Disaster risk management has also been integrated into all development and climate change adaptation plans of the country, including the Second Perspective Plan 2021-41 (GED, 2020a), Eighth five-year plan (GED, 2020b), Delta Plan 2100 (GED, 2018), National Adaptation Programme of Action (NAPA) 2005 (GoB, 2005), Bangladesh Climate Change Strategy and Action Plan (BCCSAP) 2009 (GoB, 2009), Climate Change Trust Act 2010 (GoB, 2010) and other national strategic plans. The SOD-2019 has also complied with the country's sustainable development goals (SDGs), the Sendai Disaster Risk Reduction Framework, and other international treaties and declarations. 
The BCCSAP (GoB, 2009) has formulated different adaptation, livelihood protection, early warning and risk management programmes under theme-1 (Food Security, social protection and health) and theme-2 (Comprehensive disaster management). The final program under theme two (T2P4), 'Risk management against loss of risk income and property,' specifically aimed to reduce the negative impact of disaster and increase the vulnerable people's livelihood security. This program (T2P4) is also linked to the concept of 'Risk of Loss and Damage' adopted in the Cancun Framework of Adaptation 2010 (UNFCCC, 2010) and the idea of 'compensation for L\&D' derived from Warsaw International Mechanism (WIM) for Loss and Damage 2013(UNFCCC, 2013). However, the provision of loss and damage is not directly addressed in BCCSAP as this is a recent concept which needs to be incorporated in the revised BCCSAP. The programs that promote compensation against loss and damage could finance through different international funding agencies, including UNFCCC. Additionally, the last theme (T6) of BCCSAP (Capacity building and institutional strengthening) could incorporate programs and strategies for mainstreaming loss and damage in media and strengthen capacity building programs on the subject.

\section{Towards a Resilient National Plan on Loss and Damage}

While some scholars argue that sustainable development can be seen as an adaptation strategy, others believe adaptation is a strategy for development (Kelly and Adger, 2000).). Nevertheless, it is clear that in the communities and countries still struggling to advance, the burden of loss and damage will be the most devastating (Field et al., 2012). Therefore, the most effective means to tackle climate change and disaster risk and associated loss and damage is the reduction of the underlying causes of vulnerability to climate change (Schipper, 2009). Due to existing emission levels and mitigation ambitions, climate-change losses and damages caused by extreme events and slow entry processes are likely to increase. Therefore, it is increasingly urgent to develop practical approaches to deal with loss and damage (Bijoy and Chakraborty, 2013). Moreover, it is imperative to revise the existing disaster management and climate change adaptation policy and planning process in Bangladesh to address the loss and damage emerging from climate change and associated extreme natural disasters. Therefore, we suggest formulating a loss and damage planning framework (Figure 14) and mainstreaming strategy (Figure 15) based on Bangladesh's current national disaster management plan. We recommend revising the existing policies and strategies by integrating disaster management, climate change adaptation with loss and damage. 


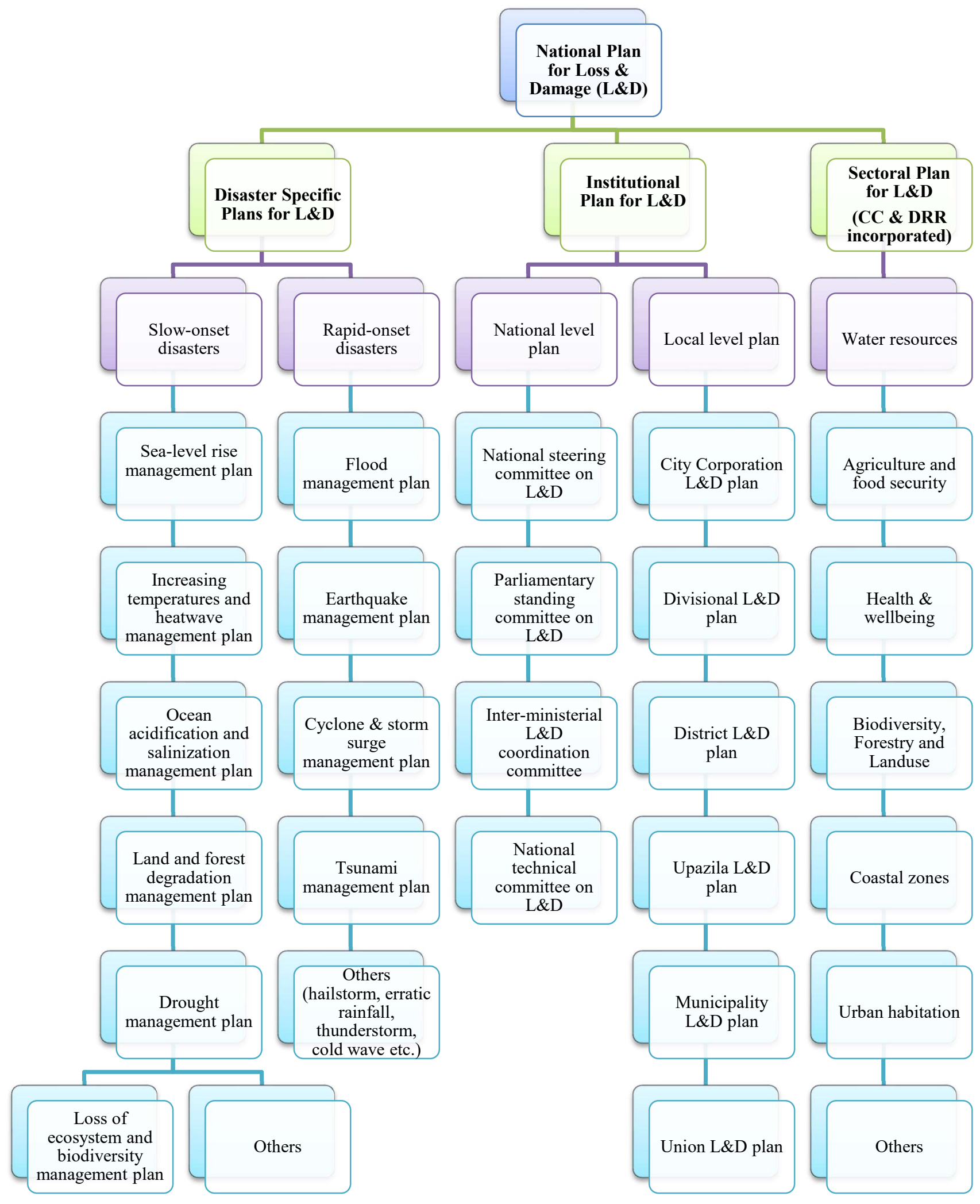

Figure 14. Proposed loss and damage (L\&D) planning framework for Bangladesh (MoDMR, 


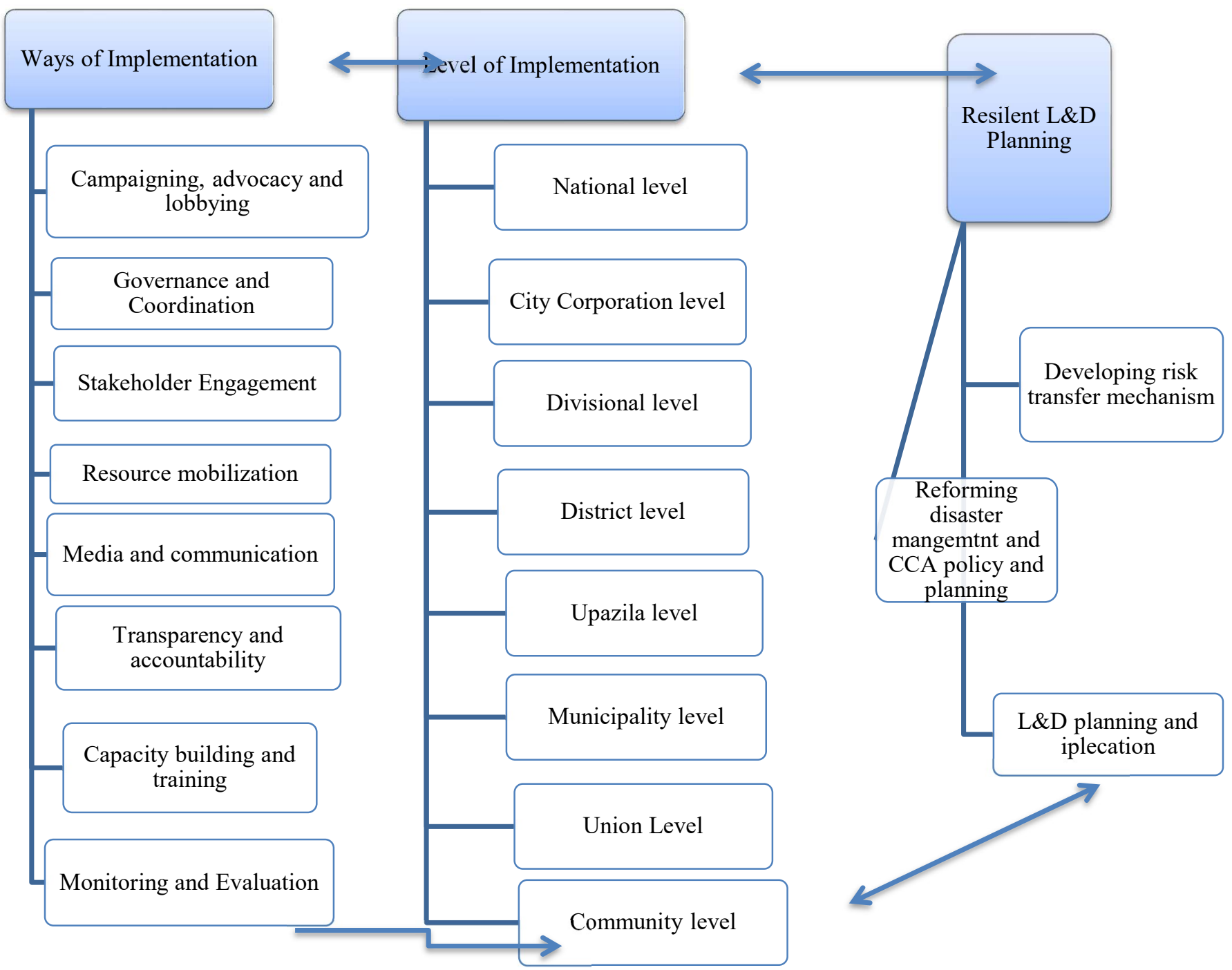

Figure 15. Proposed strategies for integrating L\&D Planning in Bangladesh (Based on MoDMR, 2017)

\section{Conclusion}

The theory of 'loss and damage (L\&D)' has recently emerged as a new dimension of international climate change negotiations, which would be considered as an additional tool for conventional climate change adaptation and mitigation efforts among the parties. Global climate change scientists, researchers and policymakers have entered into the debate whether this new framework should include the provision of compensation or not. The developed countries deny acknowledging the term 'compensation' for loss and damage due to climate change. Instead, they are proposing a 'loan' to finance climate change-induced disaster-related loss and damage. However, the vulnerable developing countries refuse this proposal and ask for approving the term compensation in the Warsaw International Mechanism (WIM) in international negotiations, including the United Nations Climate Change Conference (Conference of the Parties, COP). 
Bangladesh has taken the lead among developing countries in international climate change negotiations for a long time. In the UN climate change conference (COP), Bangladesh negotiated as a member of the Least Developing Countries (LDC) group. Once it was the group's chair but now remains in the senior group of LDC negotiators. In addition, over the times, Bangladesh had selected to become part of several key UNFCCC international bodies, including the Adaptation Fund Board, the Green Climate Fund Board, and the Executive Committee for Loss and Damage of the Warsaw International Mechanism.

Bangladesh is globally one of the most dynamic nations in climate change policy formulation, planning and action, recognizing the topic's urgency. Although Bangladesh is responsible for less than $0.35 \%$ of global greenhouse gas (GHG) emissions, still it has taken progressive actions in developing policies and action plans such as the National Adaptation Programme of Action (2005), Bangladesh Climate Change Strategy and Action Plan (BCCSAP) (2009). It has also submitted its nationally determined contributions (NDCs) to the UNFCCC and currently formulating the National Adaptation Plan (NAP), which is expected to publish by the end of 2021. The country also made numerous attempts to promote climate change financing flow, including forming the Bangladesh Climate Change Trust Fund (BCCTF) for funding climate change projects from countries own resource. It is also declaring the Climate Change Budget as part of the national budget and publishing a Fiscal Framework (CFF) that is highly appreciated in the international climate change domain. As a member of the Executive Committee for Loss and Damage of the Warsaw International Mechanism, it is high time for the country to take an exemplary role in developing countries policy, management and action plan for climate change and disaster-induced loss and damage.

Thus we are proposing the following recommendations:

a. Revise existing climate change adaptation (CCA), disaster risk reduction (DRR), disaster management (DM) policies and planning in Bangladesh by addressing the concept of loss and damage.

b. Integrate CCA, DRR and DM in the country's development planning to achieve sustainable development goals (SDGs).

c. Develop separate policy and management plan for loss and damage.

d. Initiate a separate national funding entity for loss and damage to finance vulnerable community and people to reduce their loss and cope with the impacts.

e. Start lobby and advocacy in international climate change negotiations to unite the vulnerable countries in a single platform to force the developed countries for providing compensation for loss and damage to the vulnerable countries.

Conflicts of interest: The authors do not have any potential conflicts of interest.

Funding Information: The study had received financial support from Bread for the World (BftW), Germany, to carry out the field visit and data collection.

Acknowledgments: We want to thank the data enumerators who helped us in collecting data. We would also like to express our gratitude to the experts who commented and provided opinions on the drafted questionnaires and checklists for data collection. 


\section{References}

Agrawala, S., Ota, T., Ahmed, A. U., Smith, J., \& Van Aalst, M. (2003). Development and climate change in Bangladesh: focus on coastal flooding and the Sundarbans (pp. 1-49). Paris: OECD.

BBS (Bangladesh Bureau of Statistics). (2001). Bangladesh Population Census 2001. Bangladesh Bureau of Statistics, Dhaka.

BBS (Bangladesh Bureau of Statistics). (2007). Cultural survey report of Kurigram District 2007. Bangladesh Bureau of Statistics, Dhaka.

BBS (Bangladesh Bureau of Statistics). (2010). Household Income and Expenditure Survey (HIES)-2010. Bangladesh Bureau of Statistics, Dhaka.

BBS (Bangladesh Bureau of Statistics). (2016). Bangladesh: Disaster-related Statistics 2015: Climate Change and. Natural Disaster Perspectives. Bangladesh Bureau of Statistics, Dhaka.

BBS (Bangladesh Bureau of Statistics). (2016). Household Income and Expenditure Survey (HIES)-2016. Bangladesh Bureau of Statistics, Dhaka.

Bijoy, M. R., and Chakraborty, T. R. (2013). An overview on gaps and opportunities of disaster management in Bangladesh managing climate induced disasters. Network on Climate Change, Bangladesh (NCCB), Dhaka: Bangladesh.

Botzen, W. J. W., Bouwer, L. M., and Van den Bergh, J. C. J. M. (2010). Climate change and hailstorm damage: Empirical evidence and implications for agriculture and insurance. Resource and Energy Economics, 32(3), 341-362.

Cruz, R.V., Harasawa, H., Lal, M.,Wu, S., Anokhin, Y., Punsalmaa, B., Honda, Y., Jafari, M., Li, C., and Huu Ninh, N. (2007): Asia. Climate Change 2007: Impacts, Adaptation and Vulnerability. Contribution of Working Group II to the Fourth Assessment Report of the Intergovernmental Panel on Climate Change, M.L. Parry, O.F. Canziani, J.P. Palutikof, P.J. van der Linden and C.E. Hanson, Eds., Cambridge University Press, Cambridge, UK, 469-506.

DDM (Department Of Disaster Management). (2018). Disaster Situation Report-March 2018. Department Of Disaster Management, Dhaka.

Dow, K., Berkhout, F., Preston, B. L., Klein, R. J., Midgley, G., \& Shaw, M. R. (2013). Limits to adaptation. Nature Climate Change, 3(4), 305-307.

Huq, S., Roberts, E., \& Fenton, A. (2013). Loss and damage. Nature Climate Change, 3(11), 947-949.

James, R., Otto, F., Parker, H., Boyd, E., Cornforth, R., Mitchell, D., \& Allen, M. (2014). Characterizing loss and damage from climate change. Nature Climate Change, 4(11), 938-939. 
Doelle, M., \& Seck, S. (2020). Loss \& damage from climate change: from concept to remedy?. Climate Policy, 20(6), 669-680.

Eckstein, D., Künzel, V., and Schäfer, L. (2017). Global Climate Risk Index 2021: Who suffers Most from Extreme Weather Events? Weather-related Loss Events in 2019 and 2000 to 2019. Germanwatch, Bonn

Elfil, M., and Negida, A. (2017). Sampling methods in clinical research; an educational review. Emergency, 5(1).

Eliot, I., Finlayson, C. M., \& Waterman, P. (1999). Predicted climate change, sea-level rise and wetland management in the Australian wet-dry tropics. Wetlands ecology and management, 7(1), 63-81.

Field, C. B., Barros, V., Stocker, T. F., and Dahe, Q. (Eds.). (2012). Managing the risks of extreme events and disasters to advance climate change adaptation: special report of the intergovernmental panel on climate change. Cambridge University Press.

Francis, A., and Maguire, R. (2016). Protection of refugees and displaced persons in the Asia Pacific region. Routledge.

GED (General Economics Division). (2018). Bangladesh Delta Plan 2100. Bangladesh in the 21st Century. Ministry of Planning, Government of the People's Republic of Bangladesh, Dhaka.

GED (General Economics Division). (2020a). Eighth Five Year Plan, July 2020 - June 2025: Promoting Prosperity and Fostering Inclusiveness. Ministry of Planning, Government of the People's Republic of Bangladesh, Dhaka.

GED (General Economics Division). (2020a). Making Vision 2041 a Reality: Perspective Plan of Bangladesh 2021-2041. Ministry of Planning, Government of the People's Republic of Bangladesh, Dhaka.

GoB (Government of People's Republic of Bangladesh) (2005). National Adaptation Program of Action (NAPA). Ministry of Environment and Forest, Government of People's Republic of Bangladesh (GoB), Dhaka.

GoB (Government of People's Republic of Bangladesh) (2009). Bangladesh Climate Change Strategy and Action Plan. Ministry of Environment and Forest, Government of People's Republic of Bangladesh (GoB), Dhaka.

GoB (Government of People's Republic of Bangladesh) (2010). Climate Change Trust Act 2010. Ministry of Environment and Forest, Government of People's Republic of Bangladesh (GoB), Dhaka.

IPCC (Intergovernmental Panel on Climate Change) (1990). Response strategies working group: strategies for adaption to sea level rise. In: Misdorp, R. Dronkers, J. and Spradley, J.R. (eds), Intergovernmental Panel on Climate Change Report of the Coastal Zone Management Subgroup. Ministry of Transport, Public Works and Water Management, Rijkswaterstaat, Netherlands. 
IPCC (Intergovernmental Panel on Climate Change) (2001). Climate Change 2001: Synthesis Report. A Contribution of Working Groups I, II, and III to the Third Assessment Report of the Integovernmental Panel on Climate Change [Watson, R.T. and the Core Writing Team (eds.)]. Cambridge University Press, Cambridge, United Kingdom, and New York, NY, USA, 398 pp.

IPCC (Intergovernmental Panel on Climate Change). (2000). Special report on emissions scenarios (SRES). Cambridge: Cambridge University Press.

IPCC (Intergovernmental Panel on Climate Change). (2007). Climate Change 2007: The Physical Science Basis. Contribution of Working Group I to the Fourth Assessment Report of the Intergovernmental Panel on Climate Change. Cambridge: Cambridge University Press.

IPCC (Intergovernmental Panel on Climate Change). (2014). Climate Change 2014 - Impacts, Adaptation and Vulnerability: Part A: Global and Sectoral Aspects: Working Group II Contribution to the IPCC Fifth Assessment Report. Cambridge: Cambridge University Press. doi:10.1017/CBO9781107415379

Kelly, P. M., and Adger, W. N. (2000). Theory and practice in assessing vulnerability to climate change andFacilitating adaptation. Climatic change, 47(4), 325-352.

McQuade C.V., Arthur J.T., and Butterworth I.J. (1996). Climate and hydrology. In: Finlayson C.M., Von Oertzen I. (eds) Landscape and Vegetation Ecology of the Kakadu Region, Northern Australia. Geobotany, vol 23. Springer, Dordrecht. https://doi.org/10.1007/97894-009-0133-9_2

MoDMR (Ministry of Disaster Management and Relief). (2017). National Plan for Disaster Management 2016-2020. Government of the People's Republic of Bangladesh, Dhaka.

MoDMR (Ministry of Disaster Management and Relief). (2019). Standing Orders on Disasters 2019. Government of the People's Republic of Bangladesh, Dhaka.

MPO (Master Planning Organization). (1991). National Water Management Plan: Phase II, Final Report. Master Planning Organization (MPO), Ministry of Irrigation, Water Development and Flood Control, Government of the People's Republic of Bangladesh, Dhaka.

National Research Council. (2008). Ecological impacts of climate change. National Academies Press.

Putnam, A. E., \& Broecker, W. S. (2017). Human-induced changes in the distribution of rainfall. Science advances, 3(5), e1600871

Rahaman, M. A., and Rahman, M. M. (2020). Climate Justice and Food Security: Experience from Climate Finance in Bangladesh. Environmental Policy: An Economic Perspective, 249-268.

Rahaman, M. A., Rahman, M. M., and Hossain, M. S. (2019a). Climate-Resilient Agricultural Practices in Different Agro-ecological Zones of Bangladesh. Handbook of Climate Change Resilience, 1-27. 
Rahaman, M. A., Rahman, M. M., and Rahman, S. H. (2019b). Pathways of Climate-Resilient Health Systems in Bangladesh. In Confronting Climate Change in Bangladesh (pp. 119143). Springer, Cham.

Rahman, A. and Alam, M. (2003). Mainstreaming Adaptation to Climate Change in least Developed Countries (LDCs). Working paper II, Bangladesh Country case Study, IIED, London, UK.

Schipper, E. L. F. (2009). Meeting at the crossroads?: Exploring the linkages between climate change adaptation and disaster risk reduction. Climate and Development, 1(1), 16-30.

UNFCCC (United Nations Framework Convention on Climate Change). (2010). Cancun Agreements. Retrieved February 28, 2021, from https://unfccc.int/process/conferences/pastconferences/cancun-climate-changeconference-november-2010/statements-and-resources/Agreements

UNFCCC (United Nations Framework Convention on Climate Change). (2013). Warsaw International Mechanism for Loss and Damage associated with Climate Change Impacts (WIM). Retrieved February 28, 2021, from https://unfccc.int/process/conferences/pastconferences/cancun-climate-changeconference-november-2010/statements-and-resources/Agreements

Warrick, R. A., Warrick, R. A., Barrow, E. M., \& Wigley, T. M. L. (Eds.). (1993). Climate and sea level change: observations, projections and implications. Cambridge University Press.

Yamane, Y., Hayashi, T., Dewan, A. M., and Akter, F. (2010). Severe local convective storms in Bangladesh: Part I. Climatology. Atmospheric Research, 95(4), 400-406.

Rahman, M. M. (2018, February 1). Climate Risk Transfer by Insurance Mechanism: A snapshot on the barriers and opportunities of introducing crop insurance in Bangladesh. Retrieved July 1, 2020, from http://cprdbd.org/climate-risk-transfer-by-insurance-mechanism-asnapshot-on-the-barriers-and-opportunities-of-introducing-crop-insurance-in-bangladesh/

BanglaTribune. (2018, March 30). Paddy trees have collapsed by the hailstorm, what will you eat if you do not cultivate! Retrieved June 28, 2018, from https://goo.gl/z9VPWp

Dhaka Tribune. (2018, March 30). (An English newspaper of BD) In pictures: Sudden hailstorm wreaks havoc in the northern districts. Retrieved June 24, 2018, from https://www.dhakatribune.com/image-gallery/2018/03/30/hailstorm-wrecks-havocdistricts/ 